\title{
CORRESPONDENCE
}

\section{No to quangos}

SiR - Your leading article in Nature of 5 August ("James Watt and biotechnology", p.501) asks some important questions, which you imply that only the government can answer. The difference between James Watt's doings and ours is that he was free from committees and we are not. I agree that to go back to James Watt would do no harm, provided that in going back we dismantle the bureaucratic structure that strangles our communications. Mr G.H. Fairtlough may understand the links between the Medical Research Council and the British Technology Group (and the National Enterprise Board and National Research and Development Corporation) and Celltech, but few others do Things would work so much better without these complicated bureaucracies and we and $\mathrm{Mr}$ Fairtlough would be free to compete or collaborate with each other, and free to collaborate with the research scientists.

You ask how the government can give British industry a sporting chance of survival. The answer (towards which the present government is working) is to leave it alone. Take the committees and the quangos (and the formal channel of communication between the Department of Industry and the University Grants Committee) off our backs.

S.J. STARKIE (Managing Director)

Xoma (UK) Ltd,

London SWI7, UK

\section{Cold war}

S!R - I am afraid that E.G. Dimond's suggestion to exchange $1 / 4$ million young people between the United States and the Soviet Union as an alternative to arms race (Nature 15 July, p.220) would be more unacceptable to the Soviet Union than a tenfold increase in arms buildup by the United States. Why? It would be labelled as a "philistine ploy (1) for mass infiltration of the Soviet Union by CIA agents and (2) for infecting Soviet youth with decadent bourgeois ideology to use them later as a Trojan horse to disrupt the fabric of the socialist society". This is the essence of the tragedy why every effort to reduce tensions, promote détente and so on must inevitably end in deadlock.

VIT KLEMES

National Hydrology Research Institute, Ottawa,

Ontario, Canada

\section{China syndrome}

SIR - In Nature of 19 August (p.746) you published a paper entitled "Age of the Lufeng, China, hominoid locality". One of the authors, Qi Guo-quin, appears on the contents page as $Q$. Guo-qin, which wrongly assumes Guo-qin to be the surname, and is a common mistake among Westerners.

The convention in Chinese names places the surname first, followed by the given names, which are usually hyphenated. The author is therefore Mr Qi not Mr Guo-qin. The Chinese tend to use their names in full, and the shortened form is made by dropping the given names for well known people, as in "Chairman Mao"!
There is, however, a tendency among Chinese exposed to the West to adopt our convention and place the initials of their given names before their family name. Perhaps they have become fed up with our getting their names mixed!

As scientists, the Chinese name convention should not strike us as odd - it is, after all, the same as the Linnean nomenclature!

Dulwich, London, UK

J. A. IRVING

\section{Scrapie a "gene"?}

SiR - In News and Views' R.H. Kimberlin commented on the recent suggestion by Stanley B. Prusiner of the University of California, San Francisco, that the scrapie agent is a novel proteinaceous infectious particle ${ }^{2}$.

The search for the scrapie virus proposed by Cuillé and Chelle in 1938, has been continuous. An early trickle of papers became a torrent when Chandler transmitted the disease to mice in $1961^{4}$. There have been so many variations on a virus theme that the virus hypothesis now lacks absolutely nothing. except a virus. One response to this impasse has been to call the virus "unconventional", an ingenious solution, for is not a square an unconventiona! circle?

In pursuing our suggestion in 1967 that the scrapie agent might be a small protein ${ }^{6}$, my colleagues and I applied fractionation procedures to scrapie tissues. Every experiment included control inocula of normal tissue treated precisely as the scrapie tissue, and diagnosis of scrapie was rigidly based on the presence of characteristic histological lesions in the brain?. These technical points are emphasized for two reasons. First, because few other investigators of the disease have used normal tissue controls in more than the occasional experiment, and very few have examined histologically the brain of every animal in every experiment, whether or not it showed clinical evidence of scrapie; this latter procedure is important in detecting scrapie agent in high dilution, or in unexpected circumstrances. Second, because use of this experimental routine may explain why we apparently detected scrapie agent in tissues of some non-scrapie animals.

Our findings were published in Nature in $1968^{\circ}$. In brief, in over 150 experiments scrapie did not occur in any of 2,640 mice injected with unfractionated tissue from normal sheep, goats or mice (an observation matching that of many other investigators). By contrast, scrapie occurred occasionally, and unpredictably, in mice injected with

fractionated tissue from non-scrapie animals. The possibility existed, therefore, that fractionation had released a scrapie-producing factor from non-scrapie tissue.

The obvious interpretation of our findings was that normal tissue had been contaminated with scrapie. To examine this criticism, we carried out further experiments in which attempts were made purposely to contaminate normal tissue inocula. By using unwashed glassware etc. we certainly produced some contamination, but the distribution of scrapie was different from that observed after injection of fractionated normal tissue ${ }^{9}$.

If, for a moment, it be accepted that we did indeed detect scrapie agent in normal tissue, an explanation can be offered for the apparent enigma of replication without nucleic acid that faced us initially, and now faces Prusiner. The agent may not, in fact, replicate as the disease progresses; instead - as we suggested in 1968 - replication may be simulated by an unmasking process of a particle already present. Again, if scrapie agent were a component of normal tissue, there would be a simple explanation for the widely observed but obscure phenomenon that the scrapie agent does not apparently stimulate antibody. If the agent were "self" no antibody would be expected.

In recent years, research on scrapie in sheep has largely been bypassed in favour of the experimentally-produced disease in laboratory animals, for the obvious reason that few laboratories are equipped to handle large numbers of sheep. In consequence, it is not widely recollected that many outbreaks of naturally-occurring scrapie in sheep have been associated with close mating to improve agriculturally desirable breed characteristics 10 In 1974 I reported the apparently spontaneous occurrence of scrapie in sheep selectively bred for high susceptibility to experimental scrapie $^{1 !}$. The significance of genetic make-up in susceptibility to scrapie in sheep is beyond dispute (for example ref. 12).

It may not be far-fetched, therefore, to suggest that the scrapie agent is an inhibited particle in normal tissue, released genetically in the naturally-occurring disease in sheep.

Newbury, Berks., UK

I.H. PATtison

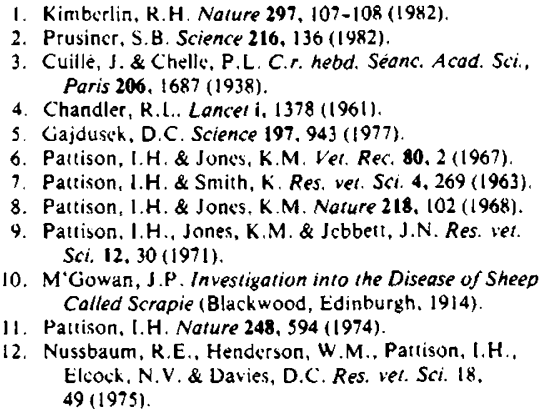

\section{To the point}

SiR - Having read Cedric A.B. Smith's letter proposing a new system for representing numbers (Nature 12 August, p.600), I am afraid that it cannot go unchallenged. He not only suggests a totally confusing system of numbers and letters, but goes on to contradict himself.

He states " 0.700 means exactly the same as .7 ", but is wrong since .7 is correct to one decimal place and 0.700 is correct to three places. And surely ".7" can be easily confused with " 7 " - referring back to an earlier paragraph in his letter ". . . what makes it worse is that especially in handwriting (and sometimes also in print) not only may dots and commas be difficult to distinguish reliably but also they may be so faint as to escape notice altogether".

Mohamed S. NanjI

Department of Biochemistry,

National Heart Hospital,

London $W l, U K$ 